\title{
Individual Rights Under a System of Dual Sovereignty: The Right to Keep and Bear Arms
}

\author{
Stephen R. McAllister ${ }^{*}$
}

I. INTRODUCTION

As a teacher of both the required, first-year course in federal constitutional law and an upper-level course on state constitutional law, I want to focus on the relationship between the Federal Constitution and the state constitutions in this Article for the 2010 Kansas Law Review Symposium. I will use the particular example of the right to keep and bear arms, recognized in the Second Amendment to the U.S. Constitution and in provisions in forty-four state constitutions, to highlight a few points about the relationship between these two constitutional regimes. My overall goal is to address briefly some of the common misconceptions I have encountered regarding the relationship between, and the roles of, the federal and state constitutions.

I identify and briefly explain three fundamental propositions about the relationship between the federal and state constitutions, using a few examples relevant to my home state of Kansas to illustrate the general propositions. The Article ultimately applies those general principles to the particular context of the individual right to possess and use firearms. I speculate about how gun rights may develop in the future under state constitutions now that the Supreme Court of the United States and the Second Amendment are an active part of this area of the law. My conclusion is that state supreme courts and state constitutions may play a prominent role in the development of gun rights, though state-based rights may be significantly limited by acts of Congress that regulate firearms and preempt any contrary state law, including state constitutions. In this instance, at least, the entity that will most influence the scope of state constitutional rights is likely to be Congress, not the Supreme Court of the United States.

* Professor of Law at the University of Kansas. 


\section{ThreE Fundamental PROPOSITIONS ABOUt THE RELATIONSHIP BETWEEN THE FEDERAL AND STATE CONSTITUTIONS}

\section{A. Proposition \#1: If Provisions of Federal Law and a State Constitution Conflict, Federal Law Prevails}

The starting point for any discussion of the relationship between the U.S. and the state constitutions is the Supremacy Clause in Article VI of the Federal Constitution, which provides:

This Constitution, and the Laws of the United States which shall be made in Pursuance thereof; and all Treaties made, or which shall be made, under the Authority of the United States, shall be the supreme Law of the Land; and the Judges in every State shall be bound thereby, any Thing in the Constitution or Laws of any State to the Contrary notwithstanding. ${ }^{1}$

This clause "make[s] clear-in explicit terms-that federal law has primacy over state law, including state constitutions, when there is a conflict between any federal law (constitutional, statutory, or even regulatory) and state law." ${ }^{2}$ There are numerous examples of the Supreme Court of the United States invalidating provisions in state constitutions that are preempted by contrary federal law. ${ }^{3}$

The Supremacy Clause is directly relevant to a recent proposal in the Kansas legislature, a proposal that also was considered in the 2010 legislative session, but which failed to garner the two-thirds majority necessary to put a proposed constitutional amendment on the ballot. In 2010, several legislators sponsored a proposed constitutional amendment that, if adopted, would have declared that no Kansan can be compelled to purchase health insurance. ${ }^{4}$ This proposal was a direct response to the federal health care reform legislation, which includes an "individual

1. U.S. CONST. art. VI, cl. 2 (emphasis added).

2. RANDy J. HOlLAND, STEPHEN R. MCAllister, JEFFrEy M. SHAMAN \& JEFFRY S. SUTTON, State CONSTITUTIONAL LAW: THE MODERN EXPERIENCE 91-92 (2010).

3. See, e.g., Romer v. Evans, 517 U.S. 620, 635-36 (1996) (striking down a state constitutional amendment as a violation of equal protection principles); U.S. Term Limits, Inc. v. Thornton, 514 U.S. 779, 837-38 (1995) (striking down a state constitutional amendment imposing term limits on a state's representatives in Congress, finding such term limits to conflict with the U.S. Constitution's explicit qualifications for such representatives); cf. Gregory v. Ashcroft, 501 U.S. 452, 456-70 (1991) (construing the federal Age Discrimination in Employment Act not to reach state judges in order to avoid preempting state constitutional mandatory-retirement-age provision).

4. See H.R. Con. Res. 5032, 83d Leg., Reg. Sess. (Kan. 2010); S. Con. Res. 1626, 83d Leg., Reg. Sess. (Kan. 2010). 
mandate" for citizens not otherwise covered by health insurance to purchase such coverage or else pay a penalty or tax. ${ }^{5}$ The 2010 Kansas proposal would have added a new article 16 to the Kansas Constitution, providing in pertinent part as follows:

\section{Article 16.- HEALTH CARE}

$\S 1$. Health care. (a) To preserve the freedom of Kansans to provide for their health care:

(1) A law or rule shall not compel, directly or indirectly, any person, employer or health care provider to participate in any health care system or purchase health insurance.

(2) A person or employer may pay directly for lawful health care services and shall not be required to pay penalties or fines for paying directly for lawful health care services. A health care provider may accept direct payment for lawful health care services and shall not be required to pay penalties or fines for accepting direct payment from a person or employer for lawful health care services.

(b) Subject to reasonable and necessary rules that do not substantially limit a person's options, the purchase or sale of health insurance in private health care systems shall not be prohibited by law or rule. ${ }^{6}$

The Kansas proposal also included an "explanatory statement" that was to be included with the measure on the ballot. That "explanation" included the following statement: "A vote for this proposition would preserve constitutionally the right of a person, employer or health care provider to be free from laws or rules compelling participation in any health care system ....,7 In 2011, essentially the same proposal has been reintroduced in the Kansas legislature. ${ }^{8}$

5. See Patient Protection and Affordable Care Act, Pub. L. 111-148, § 1501, 124 Stat. 119, 242-49 (to be codified at 42 U.S.C. § 18091; 26 U.S.C. § 5000A). Two courts have upheld the individual mandate as constitutional. See Liberty Univ., Inc. v. Geithner, No. 6:10-cv-00015-nkm, 2010 WL 4860299, at*11 (W.D. Va. Nov. 30, 2010); Thomas More Law Ctr. v. Obama, 720 F. Supp. 2d 882, 893-95 (E.D. Mich. 2010). Two other district courts have struck down the individual mandate as unconstitutional. See Florida ex rel. Bondi v. U.S. Dep’t of Health \& Human Servs., No. 3:10-cv-91-RV/EMT, 2011 WL 285683, at *40-41 (N.D. Fla. Jan. 31, 2011); Virginia ex rel. Cuccinelli v. Sebelius, 728 F. Supp. 2d 768, 788 (E.D. Va. 2010).

6. Kan. H.R. Con. Res. 5032; Kan. S. Con. Res. 1626.

7. Kan. H.R. Con. Res. 5032 § 2; Kan. S. Con. Res. 1626 § 2.

8. See John Hanna, Landwehr Revisits Plan to Block Health Care Law, WiCHITA EAgLE, Jan. 21, 2011, available at http://www.kansas.com/2011/01/21/1683912/landwehr-revisits-plan-to- 
An important question is whether such an amendment to the Kansas Constitution will have any legal effect. Despite the assertion in the "explanatory statement" about preserving "constitutionally the right” not to be compelled to participate in a health care system, ${ }^{9}$ the proposed Kansas constitutional amendment cannot override lawfully exercised federal power. ${ }^{10}$ Indeed, it is clear that, if adopted, such an amendment can have no effect on the constitutionality or application of the federal health care law to Kansas and to Kansans. If Congress has the power to enact the individual health insurance mandate, ${ }^{11}$ then no state constitutional amendment, or state statute, can preclude the operation of such a federal law on a state's citizens.

Thus, although the constitutional amendment may have value as an expression of Kansans' unhappiness and disagreement with federal law, ${ }^{12}$ it can have no legal effect in the federal arena if Congress had the power to enact the federal law. Such an amendment would, however, be binding with respect to state law, meaning that it certainly can preclude the Kansas legislature from compelling Kansans to participate in health insurance or health care programs. That result may be sufficient from the proponents' perspective, coupled with the amendment's role as a symbolic statement about the opinion of a majority of Kansans on the federal health care law.

On the other hand, because the amendment would be binding on the Kansas legislature, that body should at least be cognizant of the fact that if the amendment were adopted and the legislature later determined that it might be good policy to require certain individuals to purchase some form of health insurance, the amendment would preclude the state legislature from acting, absent another state constitutional amendment to repeal the effect of the first one. Maybe the Kansas legislature will never

block.html (reporting that Kansas House Representative Brenda Landwehr has "said she'll push a 'Health Care Freedom Amendment' even though a majority of states, including Kansas, are pursuing legal challenges to the new federal law. She said she'll introduce a new version of the measure by early February. She expects it to mirror proposals with the same name from last year, which would prohibit the state from requiring individuals or businesses to buy health insurance.”).

9. Kan. H.R. Con. Res. 5032 § 2; Kan. S. Con. Res. $1626 \S 2$.

10. See supra notes 1-3 and accompanying text.

11. This, of course, is the point of real contention. See cases cited supra note 5.

12. Kansas would not be the only state to express such an opinion through a legal enactment of no real effect. A number of states put constitutional amendments or statutory initiatives on the ballot in 2010. See, e.g., S.J. Res. 59, 52d Leg., 2d Reg. Sess. (Okla. 2010); H.R. 1764, 95th Gen. Assemb., 2d Reg. Sess. (Mo. 2010); H.R. Con. Res. 2014, 49th Leg., 1st Reg. Sess. (Ariz. 2009). All of the foregoing legislative actions have been approved. See Richard Cauchi, State Legislation and Actions Challenging Certain Health Reforms, 2011, NAT'L CONF. OF ST. LEGISLATURES (Apr. 13, 2011), http://www.ncsl.org/?tabid=18906. 
deem it proper to require anyone to purchase health insurance, in which case this may be a moot point. Nonetheless, it is at least worth considering any potential—and perhaps unintended — consequences of amending the Kansas Constitution with respect to constraining the Kansas legislature and Kansas officials such as the Governor or attorney general. State constitutions always restrict the exercise of state power, even if they cannot prevent the application of valid federal law to a state and its citizens.

To reiterate, the Supremacy Clause and numerous Supreme Court decisions make it indisputably clear that if there is a conflict between valid federal law and a state constitution, the federal law prevails. ${ }^{13}$ The Tenth Amendment, which declares that "powers not delegated to the United States by the Constitution, nor prohibited by it to the States, are reserved to the States," ${ }^{14}$ does not provide any comfort for state constitutional provisions that conflict with valid federal law. If a federal law is validly based on a power delegated to the United States-such as the power to regulate interstate commerce ${ }^{15}$ or the power to tax ${ }^{16}$-then there is no power to be "reserved" to the states, and the Tenth Amendment is inapplicable.

\section{B. Proposition \#2: State Constitutions May Provide Greater Protection of Individual Rights than Does the U.S. Constitution}

It is a relatively straightforward — and indisputable-proposition that state constitutions may accord greater protections of individual rights than the U.S. Constitution has been interpreted to provide. ${ }^{17}$ This principle is based on several factors, including (1) that the Federal Constitution always has been viewed as a "floor" of rights, not a "ceiling"; (2) that state constitutions may include express rights that are not included at all, or at least not in the same fashion, in the U.S. Constitution; and (3) that the fundamental nature of our federal system allows for variations among the states in this respect. ${ }^{18}$ Thus, if the U.S.

13. See supra notes $1-3$ and accompanying text.

14. U.S. CONST. amend. X.

15. Id. art. I, § 8, cl. 3 .

16. Id. art. I, $\S 8$, cl. 1.

17. See, e.g., Oregon v. Hass, 420 U.S. 714, 719 (1975) (“[A] state is free as a matter of its own law to impose greater restrictions on police activity than those this Court holds to be necessary upon federal constitutional standards.”); Cooper v. California, 386 U.S. 58, 62 (1967) (noting that states have the "power to impose higher standards on searches and seizures than required by the Federal Constitution”).

18. See Dorothy Toth Beasley, Essay, Federalism and the Protection of Individual Rights: The 
Constitution does not protect particular speech or religious practices, prevent the government from taking private property for certain purposes, prevent particular police conduct, guarantee education rights to children, provide for same-sex marriage, or guarantee a woman's right to terminate a pregnancy, nothing in American law or tradition precludes the states from recognizing any and all of these rights under their state constitutions.

The examples of this proposition are numerous, so I will highlight only two from Kansas by way of illustration. The first example involves education. The Supreme Court of the United States held almost four decades ago that there is no federal constitutional "right to education" because there is no express provision in the U.S. Constitution granting such a right and education is not a "fundamental right." " The Court has shown no inclination to revisit or revise that holding, but the state courts have been far from inactive in the area of education. Instead, the financing of public education has been perhaps one of the most active areas of state constitutional law over the past few decades.

That certainly was true of Kansas during the past ten years. In state court litigation challenging the Kansas funding system for K-12 schools, the Kansas Supreme Court expressly addressed educational rights under the Kansas Constitution. In sharp contrast to the U.S. Constitution, the Kansas Constitution has an article-article VI-explicitly devoted to education. Section 1 of that article provides that the "legislature shall provide for intellectual, educational, vocational and scientific improvement by establishing and maintaining public schools."20 Section 6(b) further provides that the "legislature shall make suitable provision for finance of the educational interests of the state.",21

In the Montoy v. State litigation, ${ }^{22}$ the Kansas Supreme Court relied solely on these state constitutional provisions to conclude that the school funding system then in place failed to comply with state constitutional requirements. The court stated that the funding system did not violate the federal Equal Protection Clause. ${ }^{23}$ Instead, the court concluded that the Kansas school funding system contravened article VI of the Kansas

American State Constitutional Perspective, 11 GA. ST. U. L. REV. 681, 695-96 (1995).

19. See San Antonio Indep. Sch. Dist. v. Rodriguez, 411 U.S. 1, 35-37 (1973).

20. KAN. CONST. art. VI, § 1.

21. Id. art. VI, § 6(b).

22. There are four decisions in Montoy, often referred to as Montoy I, II, III, and IV: Montoy v. State (Montoy I), 62 P.3d 228 (Kan. 2003); Montoy v. State (Montoy II), 120 P.3d 306 (Kan. 2005); Montoy v. State (Montoy III), 112 P.3d 923 (Kan. 2005); Montoy v. State (Montoy IV), 138 P.3d 755 (Kan. 2006).

23. Montoy II, 120 P.3d at 308. 
Constitution. $^{24}$ This is a clear example-by no means unique to Kansas $^{25}$ —of a state constitution providing significantly greater rights than does the Federal Constitution. Furthermore, a majority of the Kansas Supreme Court, at least prior to the untimely passing of Chief Justice Davis, has endorsed the proposition that education is a fundamental right under the Kansas Constitution, ${ }^{26}$ which is indisputably not the case under the U.S. Constitution. ${ }^{27}$

A second example is the right to a jury trial in criminal cases, recognized in the Sixth Amendment to the U.S. Constitution ${ }^{28}$ and in sections 5 and 10 of the Kansas Constitution's Bill of Rights. ${ }^{29}$ In the context of juvenile proceedings, forty years ago the U.S. Supreme Court held-in an admittedly somewhat confusing set of opinions-that juveniles do not have a federal constitutional right to a jury trial. ${ }^{30}$ For many years, the Kansas Supreme Court took the same view under the Kansas Constitution. ${ }^{31}$ But, in 2008, in In re L.M., the Kansas Supreme Court reversed course and held that juveniles have a constitutional right to a jury trial under both the federal and Kansas constitutions. ${ }^{32}$

The holding in L.M., that there is a federal constitutional right to a jury trial in juvenile cases, is open to serious debate, not least because the

24. See id. at 308-10.

25. See, e.g., Richard E. Levy, Gunfight at the K-12 Corral: Legislative vs. Judicial Power in the Kansas School Finance Litigation, 54 U. KAN. L. REV. 1021, 1025-26 (2006); Jeffrey S. Sutton, Essay, San Antonio Independent School District v. Rodriguez and Its Aftermath, 94 VA. L. REV. 1963, 1973-74 (2008).

26. Montoy II, 120 P.3d at 311 (Beier, J., concurring) ("I disagree with the holding ... that education is not a fundamental right under the Kansas Constitution. I believe it is.”); id. at 318 (Luckert, J., concurring) ("I would find that education is a fundamental right under the Kansas Constitution.”); Montoy IV, 138 P.3d at 766 (Rosen, J., concurring) (“Every child in Kansas has a fundamental right to an education guaranteed by the Kansas Constitution.”).

27. See supra note 19 and accompanying text.

28. "In all criminal prosecutions, the accused shall enjoy the right to a speedy and public trial, by an impartial jury of the State and district wherein the crime shall have been committed." U.S. CONST. amend. VI.

29. “The right of trial by jury shall be inviolate.” KAN. CONST. Bill of Rights § 5. "In all prosecutions, the accused shall be allowed . . . a speedy public trial by an impartial jury of the county or district in which the offense is alleged to have been committed.” Id. § 10 .

30. McKeiver v. Pennsylvania, 403 U.S. 528, 545 (1971).

31. See, e.g., In re L.A., 21 P.3d 952, 963 (Kan. 2001) (holding that there is no federal or state constitutional right to a trial by jury in proceedings under the Kansas Juvenile Offenders Code); Findlay v. State, 681 P.2d 20, 22 (Kan. 1984) (same), abrogated by In re L.M., 186 P.3d 164 (Kan. 2008).

32. 186 P.3d at 170-72. An in-depth examination of the L.M. decision is beyond the scope of this Article. For a thorough analysis of the court's opinion, as well as a discussion of how a juvenile's right to jury trial should operate, see generally Andrew Treaster, Note, Juveniles in Kansas Have a Constitutional Right to a Jury Trial. Now What? Making Sense of In re L.M., 57 U. KAN. L. REV. 1275 (2009). 
only U.S. Supreme Court precedent on point holds to the contrary. ${ }^{33}$ But even assuming for the sake of argument both that the Kansas Supreme Court is wrong on that point and that the U.S. Supreme Court precedent rejecting such a right remains valid federal precedent, L.M. is an interesting example of the proposition I am discussing in this section. Indeed, even were it absolutely clear that there is no federal right to a jury trial in juvenile cases, nothing in the U.S. Constitution precludes Kansas from recognizing such a right under the Kansas Constitution, as the court did in L.M.

There may in fact be much stronger or more defensible reasons to recognize such a right under state law rather than federal law. For example, one of the Kansas constitutional jury-trial provisions-on which the concurrence in L.M. relied but on which the majority curiously did not ${ }^{34}$ - speaks in emphatic terms not directly mirrored in the Federal Constitution: "The right of trial by jury shall be inviolate." 35 Furthermore, under the Kansas Constitution, the Kansas Supreme Court can take account of factors unique to Kansas, such as (1) state constitutional language that differs significantly from federal constitutional provisions; ${ }^{36}$ (2) the history and evolution of the Kansas juvenile justice system, which arguably has come more and more to resemble the adult criminal justice system-including lessening the emphasis on juvenile rehabilitation and increasing the emphasis on retribution and punishment; ${ }^{37}$ and (3) the practical impact such a ruling will have on the juvenile justice system in Kansas, including the effect on prosecutors, the defense bar, and the trial courts. ${ }^{38}$

33. See supra note 30 and accompanying text. Although acknowledging that the U.S. Supreme Court has never revisited or revised its decision in McKeiver, and that no state supreme court has ever held that the Sixth Amendment requires a jury trial in juvenile cases-a proposition that the L.M. majority oddly characterized as "not find[ing] total support from the courts in some of our sister states"- the L.M. majority nonetheless remained "undaunted in [its] belief that juveniles are entitled to the right to a jury trial guaranteed to all citizens under the Sixth and Fourteenth Amendments to the United States Constitution.” In re L.M., 186 P.3d at 171 (emphasis added).

34. See In re L.M., 186 P.3d at 172-73 (Luckert, J., concurring) ("I concur in the majority's conclusion that L.M. has a constitutional right to trial by jury, but I base this conclusion on the rights guaranteed by $\S 5$ of the Kansas Constitution Bill of Rights rather than the Sixth Amendment to the United States Constitution or $\S 10$ of the Kansas Constitution Bill of Rights, which are relied upon by the majority.").

35. KAN. CONST. Bill of Rights $\S 5$.

36. See Holland ET AL., supra note 2, at 153 ("When the language of the state constitutional guarantee differs materially from its federal counterpart, the state courts have an additional reason for construing their constitutions differently.").

37. See generally In re L.M., 186 P.3d 164 (noting that the juvenile justice system is now patterned after the adult criminal system).

38. See HollAND ET AL., supra note 2, at 139 (noting that state courts can "allow local 
Moreover, a rule under the Kansas Constitution affects only Kansas, leaving other states free to interpret their jury-trial rights as they deem appropriate under state law and local conditions. A Sixth Amendment ruling by the U.S. Supreme Court, in marked contrast, would establish a baseline requirement for all states, which may be one reason why, at least in some instances, the U.S. Supreme Court may be reluctant to announce or recognize new federal constitutional rights or to interpret federal individual-rights provisions aggressively in favor of greater rights. Lastly, by also relying on the state constitution as an independent basis for recognizing a jury-trial right in L.M., the Kansas Supreme Court precluded Kansas from appealing that court's debatable holding under federal law to the U.S. Supreme Court. ${ }^{39}$ I am not suggesting that the Kansas Supreme Court had any tactical strategy in this regard but, rather, want to highlight an important point about the relationship between the federal and state constitutions: not only may state supreme courts interpret state constitutions more expansively than the U.S. Supreme Court has interpreted the Federal Constitution, but such decisions are immune from U.S. Supreme Court review, so long as they are based clearly and independently on state law. ${ }^{40}$

Of course, state supreme courts often follow federal law when interpreting analogous provisions of state constitutions. The Kansas Supreme Court has described its interpretation of the Kansas Constitution in this regard as follows:

While we can recognize a broader right under the Kansas Constitution, we have not explicitly done so in our [double jeopardy] cases. Generally, provisions of the Kansas Constitution which are similar to the Constitution of the United States have been applied in a similar manner. No reason has been suggested why we should do otherwise in the area of double jeopardy. ${ }^{41}$

conditions . . . to affect their interpretation of a constitutional guarantee").

39. See Michigan v. Long, 463 U.S. 1032, 1041 (1983) (stating that the Supreme Court will not review state court decisions raising issues of federal law if the state courts clearly rely on independent and adequate state-law grounds for their ultimate decision).

40. See id.

41. State v. Schoonover, 133 P.3d 48, 77 (Kan. 2006) (internal citations omitted); see also State v. Morris, 880 P.2d 1244, 1254-56 (Kan. 1994) (stating that the right to counsel under section 10 of the Kansas Constitution's Bill of Rights provides the same protection as the Fifth and Sixth Amendments of Federal Constitution); State v. Schultz, 850 P.2d 818, 823 (Kan. 1993) (noting that the scope of section 15 of the Kansas Constitution's Bill of Rights is identical to the Fourth Amendment); State ex rel. Tomasic v. Kan. City, Kan. Port Auth., 636 P.2d 760, 777 (Kan. 1981) (explaining that sections 1 and 2 of the Kansas Constitution's Bill of Rights are given the same effect as the Fourteenth Amendment). The Kansas Supreme Court also has indicated that, in an 
As the Kansas cases make clear-and many similar cases can be found in just about every state-the proposition that a state constitution may provide greater rights than does the Federal Constitution does not necessarily mean that a state supreme court will interpret any given state constitutional provision or guarantee to do so. ${ }^{42}$

\section{Proposition \#3: State Constitutions in Theory Also May Provide Less Protection than the U.S. Constitution, but in Such Circumstances, They Are Rendered Ineffective by Federal Preemption}

A perhaps trickier conceptual proposition, but one that is equally as strong and accurate as the first two propositions identified above, is the notion that state constitutions also can provide less protection of a particular right than the Federal Constitution provides. This is in a sense a theoretical proposition because a state constitutional interpretation giving lesser rights than the U.S. Constitution cannot have legal effect so long as the federal constitutional "floor" remains in effect. ${ }^{43}$ But this point highlights that on some very important and potentially controversial issues, the state constitutions may enshrine different value judgments than those found in the U.S. Constitution, and not always in favor of recognizing greater rights.

Two controversial examples will illustrate this point. First, many states, including Kansas, define "marriage" as "constituted by one man and one woman only." 44 Indeed, the Kansas Constitution expressly states that "[a]ll other marriages are declared to be contrary to the public policy of this state and are void." 45 Thus, “[n]o relationship, other than a

appropriate case, Kansas constitutional protections in the criminal procedure area might have a more expansive meaning than the analogous provisions in the U.S. Constitution. See, e.g., State v. Scott, 183 P.3d 801, 830 (Kan. 2008) (rejecting a state constitutional challenge to the Kansas death penalty statute, but observing that "[o]ur decision today should not be construed to preclude future interpretation of $\S 9$ [of Kansas's Bill of Rights, which prohibits cruel or unusual punishment,] when considering the proportionality of a criminal sentence. In such a circumstance, we are free to further consider the historical record and decide whether $\S 9$ should be interpreted in a manner which deviates from that given to the Eighth Amendment by the United States Supreme Court.”).

42. There is, however, an interesting and quite plausible argument that the tradition of interpreting state constitutions by reference to interpretations of analogous provisions in the Federal Constitution may have it backwards. For an interesting article proposing that perhaps the Supreme Court of the United States should be looking to state supreme court interpretations of state constitutions in deciding what various provisions in the U.S. Constitution mean, see generally Joseph Blocher, Reverse Incorporation of State Constitutional Law, 84 S. CAL. L. REV. 323 (2011).

43. See Beasley, supra note 18, at 695.

44. KAN. CONST. art. 15, § 16(a).

45. Id. 
marriage, shall be recognized by the state as entitling the parties to the rights or incidents of marriage." 46

In August 2010, a federal district court held that prohibiting samesex marriages violates the U.S. Constitution. ${ }^{47}$ That case is now on appeal to the U.S. Court of Appeals for the Ninth Circuit ${ }^{48}$ and undoubtedly will be pursued to the Supreme Court, no matter how the Ninth Circuit rules. It is entirely possible that the U.S. Supreme Court ultimately will review this case or another case raising the same issues. If the Supreme Court were to rule that the Federal Constitution recognizes and protects an individual right to marry a person of the same sex, then no state-including Kansas - could give legal effect to state constitutional prohibitions on same-sex marriage. ${ }^{49}$ The result would be a situation in which some states clearly desire to provide less constitutional protection of individual rights, but the federal constitutional "floor" precludes them from giving effect to their constitutional orientation or preferences.

A second example arises in the context of abortion and a woman's right to choose whether to terminate a pregnancy. Some states certainly would prefer that abortion be illegal in all or virtually all circumstances, and they may ultimately express that view in their state laws or constitutions. $^{50}$ But those preferences can be given no more legal effect than the Supreme Court's federal constitutional abortion jurisprudence

46. Id. art. 15, § 16(b).

47. Perry v. Schwarzenegger, 704 F. Supp. 2d 921, 1003 (N.D. Cal. 2010).

48. On January 4, 2011, the Ninth Circuit certified to the California Supreme Court a question about the standing of the proponents of the initiative, who are appealing the district court's ruling because state officials did not appeal. See Perry v. Schwarzenegger, 628 F.3d 1191, 1193 (9th Cir. 2011).

49. See Beasley, supra note 18 , at 695.

50. Some states, and perhaps even the U.S. Congress, may consider either constitutional amendments or legislative enactments that would declare that life begins at conception or fertilization. See, e.g., H.R. 490, 62d Leg., 2011 Sess. (Mont. 2011). Colorado voters defeated such a proposal in November 2010. See Electa Draper, Amendment 62 "Personhood" Initiative Sinks by 3-1 Margin, DENV. Post, Nov. 3, 2010, at B2. But there are ongoing efforts to pursue such proposals in a number of states. See Cheryl Wetzstein, Mississippi Voters Can Decide 'Personhood,' WASH. TIMES, Oct. 28, 2010, at A6. These efforts are not limited to the state level. A "Life at Conception Act” was introduced in the U.S. Senate on January 25, 2011. See S. 91, 112th Cong. (2011). Some states already have statutes that declare life begins at conception or fertilization. See, e.g., Mo. REV. STAT. § 1.205.1(1) (2000) (stating that "[t]he life of each human being begins at conception”). One scholar who has surveyed the fifty states concluded that it is likely that thirteen states would protect a right to abortion under their state constitution if Roe $v$. Wade were overruled, while thirty-seven states probably would not recognize such a state constitutional right. See generally PAUL BENJAMIN LINTON, ABORTION UNDER STATE CONSTITUTIONS: A STATE-BY-STATE ANALYSIS (2008) (analyzing abortion rights under all fifty state constitutions). 
allows. In other words, no state currently can ban or criminalize all abortions, although some might prefer that choice as a matter of state policy or state constitutional law.

Only if the Supreme Court were, for example, to overrule Roe $v$. Wade $^{51}$ and declare that the U.S. Constitution neither creates nor protects a woman's individual right to decide whether to terminate a pregnancy could these states ever give legal effect to their expressed preferences. Of course, deciding which side in the abortion debate provides for greater or lesser protection of individual rights depends, I suppose, on one's perspective. For the pro-choice side, federal law currently provides greater protection of women's rights than some states might recognize if they were free to determine the scope of such rights. For the pro-life side, federal law provides less protection for the rights of the unborn, and so I assume their view would be that state law could in fact provide greater protection of individual rights, if unconstrained by the federal constitutional doctrine recognized in Roe and subsequent cases.

In any event, these two examples are intended to illustrate that there may well be circumstances in which at least some states desire to provide less protection of certain individual rights than the Federal Constitution has been held to require. Thus, it is perhaps inaccurate to think of state constitutional law as necessarily a one-way ratchet, always moving in favor of the states recognizing greater individual rights than the Supreme Court has interpreted the U.S. Constitution to provide. The states certainly may, in given instances, prefer a very different recognition of rights than provided by the Federal Constitution, and those state preferences may go in either direction-in favor of greater protection or in favor of lesser protection.

\section{APPLYING THE FUNDAMENTAL PROPOSITIONS IN THE CONTEXT OF THE INDIVIDUAL RIGHT TO POSSESS AND USE FIREARMS}

A. Individuals Have a Limited Right to Keep and Bear Arms Under the Second Amendment, and This Right Applies Against State and Local Governments

For a remarkable 220 years, the Supreme Court never decided the question whether the Second Amendment to the U.S. Constitution recognizes an individual right to own, possess, and use firearms. The Second Amendment's elliptical language is well-known and has been 
much debated by scholars and others over the years, ${ }^{52}$ but in District of Columbia v. Heller, ${ }^{53}$ the Supreme Court finally addressed the provision head-on. Heller involved a District of Columbia law that, among other things, generally prohibited the possession of handguns in the District and required that long guns, such as rifles and shotguns, generally remain unloaded and disassembled or disabled by a trigger lock when kept in a person's home. ${ }^{54}$

The Supreme Court held that the Second Amendment (1) creates an individual right to keep and bear arms that is not limited by reference to the militia purpose expressly recognized in the amendment and (2) the D.C. total ban on common handguns and restrictions on the readiness of long guns in the home were unconstitutional. ${ }^{55}$ Importantly, for state constitutional law purposes, the Court issued the following explicit caveat: "Like most rights, the right secured by the Second Amendment is not unlimited." 56 The Court pointedly-and without any further explanation-cautioned that,

[a]lthough we do not undertake an exhaustive historical analysis today of the full scope of the Second Amendment, nothing in our opinion should be taken to cast doubt on longstanding prohibitions on the possession of firearms by felons and the mentally ill, or laws forbidding the carrying of firearms in sensitive places such as schools and government buildings, or laws imposing conditions and qualifications on the commercial sale of arms. ${ }^{57}$

The Court did not specify-indeed it expressly declined to specify or articulate—a particular test or level of scrutiny for Second Amendment challenges. ${ }^{58}$

Because Heller involved a federal enclave and thus a "federal" law, not a state or local government enactment, it did not resolve the question

52. See, e.g., Don B. Kates, Jr., Handgun Prohibition and the Original Meaning of the Second Amendment, 82 MicH. L. REV. 204, 211-51 (1983) (examining the literal language, proposal and ratification, philosophical and historical background, and contemporary understandings of the Second Amendment).

53. 554 U.S. 570 (2008).

54. See id. at $574-75$.

55. See id. at 586, 595, 630.

56. Id. at 626 .

57. Id. at $626-27$.

58. The lower courts have been struggling with the test or level of scrutiny ever since Heller was decided. See, e.g., United States v. Chester, 628 F.3d 673, 678-79 (4th Cir. 2010) (wrestling with "the question of how to evaluate [a] Second Amendment challenge" and surveying the approaches that are being developed in the circuits following Heller). 
whether the Second Amendment right recognized there also applies against the states and local governments. The Court resolved that issue in McDonald v. City of Chicago, ${ }^{59}$ with a majority holding that the right recognized in Heller applies against the states and local governments. A plurality of four relied on the "incorporation doctrine" developed under the Fourteenth Amendment's Due Process Clause, ${ }^{60}$ and Justice Thomas concurred on the ground that the right applies as a privilege or immunity of federal citizenship under the Fourteenth Amendment. ${ }^{61}$ McDonald, however, does not further define or explain the right that Heller recognized, either in terms of its substance or the appropriate level of judicial scrutiny to apply to Second Amendment challenges to federal, state, or local laws regulating the sale, possession, or use of firearms.

\section{B. Because the Individual Right to Keep and Bear Arms Under the Second Amendment Does Not Appear to Disturb Various Significant Federal Firearms Regulations, State Courts and State Constitutions May Be Precluded from Recognizing Greater Gun Rights than the Second Amendment Provides}

My goal in this Article is not to explore or debate the wealth of materials and arguments that have been brought to bear on Second Amendment issues. Rather, my point is to consider briefly the newly recognized federal Second Amendment right of individuals as that right relates to state constitutional provisions that recognize rights to possess and use firearms. Indeed, as the table appended to this Article demonstrates, forty-four state constitutions expressly recognize and protect some form of gun rights. ${ }^{62}$ Further, it is entirely possible that some state supreme courts either already have or in the future will interpret their state constitutions to provide greater protection of an individual's right to keep and bear arms than the U.S. Supreme Court ultimately decides that the Second Amendment requires. ${ }^{63}$

59. 130 S. Ct. 3020 (2010).

60. See id. at 3050 (plurality opinion) ("We therefore hold that the Due Process Clause of the Fourteenth Amendment incorporates the Second Amendment right recognized in Heller.”).

61. Id. at 3059 (Thomas, J., concurring in part and concurring in the judgment).

62. See Appendix infra Part V. For a slightly older survey that includes citations to state cases interpreting these provisions, see Eugene Volokh, Reference Material, State Constitutional Rights to Keep and Bear Arms, 11 TEX. ReV. L. \& POL. 191, 206-07 (2006).

63. See, e.g., Britt v. State, 681 S.E.2d 320, 322-23 (N.C. 2009) (holding that a state constitutional provision virtually identical to the Second Amendment precluded the state from denying the right to keep and bear arms to a nonviolent felon who had lived peacefully and committed no further violations of the law for seventeen years since his felony conviction). 
As the table illustrates, a few state constitutions have language that tracks the Second Amendment, ${ }^{64}$ though it is worth remembering that several state constitutional firearms-rights provisions predate the Second Amendment, ${ }^{65}$ and thus it is perhaps the Second Amendment that mimics the language of state constitutions, not vice versa. ${ }^{66}$ In total, forty-four state constitutions currently contain a gun-rights provision. ${ }^{67}$ At least thirty state constitutions explicitly refer to a right to keep and bear arms in self-defense, variously phrased as defense of "self," "home," "themselves," or in other ways. ${ }^{68}$ A few state constitutions refer to the right as relating to the "common defense," right without specifying any purpose-militia, self-defense, common defense, or otherwise. $^{70}$

Indeed, some states, such as Kansas, appear to have adopted wording to make clear that their state constitutional provision recognizes rights separate and apart from any militia purpose or notions, thus granting rights much broader than the "collective right" view of the Second Amendment, and perhaps even potentially broader than the Second Amendment as interpreted in Heller. For example, in November 2010, Kansans overwhelmingly approved an amendment to section 4 of the Kansas Bill of Rights. ${ }^{71}$ Section 4 had provided that "[t]he people have the right to bear arms for their defense and security."72 The 2010 amendment changed section 4 to state that "[a] person has the right to keep and bear arms for the defense of self, family, home and state, for

64. The state constitutions of Alaska, Hawaii, North Carolina, and South Carolina track the Second Amendment language verbatim, or very nearly so. The Virginia Constitution reads similarly to focus on a militia purpose, but the phrasing is different than the Second Amendment. See Appendix infra Part V.

65. This is a point that the majority in Heller made in interpreting the Second Amendment to recognize an individual right, rather than solely a collective, militia-related right. See Dist. of Columbia v. Heller, 554 U.S. 570, 600-02 (2008).

66. That obviously is not the case with respect to Alaska and Hawaii, but it could well be true of the Carolina constitutions and the Virginia Constitution, as well as other founding-era state constitutions that subsequently have been amended to alter the language by which they recognize gun rights.

67. See Appendix infra Part V. Only California, Iowa, Maryland, Minnesota, New Jersey, and New York do not have gun-rights provisions in their state constitutions. See Appendix infra Part V.

68. See provisions quoted in Appendix infra Part V.

69. Arkansas, Massachusetts, and Tennessee have provisions making this reference. See Appendix infra Part V.

70. This small group includes the constitutions of Georgia, Idaho, Illinois, Louisiana, Maine, and Rhode Island. See Appendix infra Part V.

71. See Jan Biles, Two Amendments Look to Have Passed, TOPEKA CAP.-J., Nov. 3, 2010, at 7A.

72. KAN. CONST. Bill of Rights $§ 4$ (amended in 2010). 
lawful hunting and recreational use, and for any other lawful purpose.,73 As the ballot measure explained-or repeated, "[t]he purpose of this amendment is to preserve constitutionally the right of a person to keep and bear arms for the defense of self, family, home and state, and for all other lawful purposes, including hunting and recreation.,74

Proponents of the measure stated, for example, that “'[i]t's just making certain we have an individual, not a collective right to gun ownership in Kansas.",75 One opponent charged that the amendment was pointless: “"The U.S. Supreme Court, . . . in two different decisions over the last two years has determined that the 2nd Amendment is applicable to the states.... This is completely ridiculous and unnecessary." 76 Superficially, the observation that the Second Amendment already protects gun rights and thus makes state constitutional provisions redundant or unnecessary might seem persuasive, but Heller makes clear-if that is the right way to describe a decision that specifically fails to articulate a standard for evaluating Second Amendment claims - that the right the Court recognizes is far from powerful and expansive. ${ }^{77}$ Indeed, the Heller opinion goes out of its way to reassure everyone that a host of federal statutes regulating firearms are constitutional. ${ }^{78}$ Thus, it is not at all clear how much substance there is to Second Amendment rights, ${ }^{79}$ and it may make considerable sense for a state constitutional guarantee to be clear and explicit, unlike Heller and the Second Amendment. ${ }^{80}$

73. S. Con. Res. 1611, 83d Leg., 2009 Reg. Sess. § 1 (Kan. 2009).

74. Id. $\S 2$.

75. Rachel Whitten, Constitutional Ballot Questions Leave It Up for Voters to Decide, KANSASREPORTER.ORG, Oct. 25, 2010, http://www.kansasreporter.org/legislative/issues/68123.aspx (quoting then-State Senator Tim Huelskamp, a current member of the U.S. House of Representatives).

76. Douglas Kennedy, A Second 2nd Amendment? Kansas Initiative Would Reaffirm Right to Bear Arms, Fox NEws (Sept. 16, 2010), http://politics.blogs.foxnews.com/2010/09/16/second-2ndamendment-kansas-initiative-would-reaffirm-right-bear-arms (quoting Paul Helmke of the Brady Campaign to Prevent Gun Violence).

77. See Dist. of Columbia v. Heller, 554 U.S. 570, 626-27 (2008).

78. See id.

79. See, e.g., Anna Stolley Persky, An Unsteady Finger on Gun Control Laws: Despite 2nd Amendment Cases, Firearms Codes Are Moving Targets, A.B.A. J., Dec. 2010, at 14, 14 (discussing various post-Heller Second Amendment challenges and observing that "[w]hile there have been challenges throughout the country to local, state and federal gun laws, few have been successful”).

80. For Kansas in particular, at least two Kansas Supreme Court decisions have held that section 4 of the Kansas Bill of Rights only provides a collective right to bear arms for militia purposes, not an individual right. See City of Junction City v. Lee, 532 P.2d 1292, 1295 (Kan. 1975); City of Salina v. Blaksley, 83 P. 619, 620 (Kan. 1905). One case struck down a gun-control ordinance as "unconstitutionally overbroad" without ever mentioning section 4, instead seeming to rely on due process principles and apparently concluding that the city ordinance at issue was 
At the same time, however, the Supremacy Clause-in combination with the federal statutes explicitly mentioned and blessed in Hellermay result in states having limited power to guarantee or provide to their citizens gun rights broader than those the Supreme Court recognizes as Second Amendment rights. This is not because the Second Amendment itself restricts states from choosing to recognize more expansive gun rights. Under our system of dual sovereignty, federal Bill of Rights guarantees are floors of individual-rights guarantees, not ceilings, ${ }^{81}$ so in the absence of any federal statutes in this area, states would be free to recognize significantly broader gun rights than the Second Amendment may be held to provide.

The rub, however, is all of those federal statutes that the Heller Court expressly approved - though with no explanation. ${ }^{82}$ To get a sense of the federal statutes to which the Court was referring, the best source is the amicus curiae brief that the United States filed in Heller. Remember that although the District of Columbia is a unique federal enclave rather than a state, the United States was not a party to the case, which was between Mr. Heller and the District of Columbia local government. ${ }^{83}$ Nonetheless, the United States filed an amicus brief in the case, and the Court permitted the Solicitor General of the United States to participate extensively in the Heller oral argument. In light of this fact, it seems quite likely that the Heller majority's references to federal statutes regulating firearms were made with the U.S. brief in mind.

The United States argued that the Second Amendment creates an individual right to keep and bear arms, but that the right is limited and subject to considerable regulation by Congress. ${ }^{84}$ Indeed, the brief identified four categories of federal statutes regulating firearms, all of which the government argued were constitutional even if the Court recognized an individual right in the Second Amendment to keep and

irrational. See City of Junction City v. Mevis, 601 P.2d 1145, 1150-51 (Kan. 1979). In the most recent Kansas case raising a section 4 claim, the court concluded that a prohibition on concealed weapons did not violate the Second Amendment and further reaffirmed the Blaksley precedent that section 4 did not preclude concealed-carry regulations. See State v. Knight, 218 P.3d 1177, 1188-90 (Kan. Ct. App. 2009). In light of these cases, it is not at all clear that before its amendment in 2010, section 4 of the Kansas Bill of Rights recognized an individual right to keep and bear arms, nor would the scope of any such right have been at all certain under the pre-2010 version of that provision. Thus, amending section 4 was a logical and potentially important option for those Kansans who prefer a strong state constitutional right to keep and bear arms.

81. Beasley, supra note 18, at 695.

82. See Heller, 554 U.S. at 626-27.

83. See id. at 575-76.

84. See Brief for the United States as Amicus Curiae at 20-21, Heller, 554 U.S. 570 (No. 07290), 2008 WL 157201. 
bear arms: (1) statutes banning particular types of weapons, such as machine guns or firearms that can evade metal detectors or $\mathrm{x}$-ray machines; ${ }^{85}$ (2) statutes prohibiting certain persons from possessing firearms, such as convicted felons, fugitives from justice, those with certain drug convictions, those found mentally incompetent, aliens illegally in the U.S., those dishonorably discharged from the armed forces, those who have renounced their U.S. citizenship, certain persons subject to restraining orders, and those convicted of certain crimes of domestic violence; ${ }^{86}$ (3) statutes prohibiting firearms in certain locations, such as federal government facilities, the Capitol and its grounds, and aircraft; ${ }^{87}$ and (4) statutes regulating commercial transactions involving firearms, including the manufacture, sale, and importation of firearms. ${ }^{88}$ After reciting these numerous federal statutes, the brief noted that the Attorney General had "made clear that the United States 'can and will continue to defend vigorously the constitutionality, under the Second Amendment, of all existing federal firearms laws.",89 The brief later argued the constitutionality of categories (1), (2), and (4) at some length. ${ }^{90}$

So long as Congress has considerable power to regulate who may possess firearms, where they may possess them, and under what terms and conditions they may acquire them, the Supremacy Clause guarantees that any such federal statutory restrictions-or administrative regulations, such as, for example, those that might be promulgated by the Bureau of Alcohol, Tobacco, and Firearms or some other agency or federal entity at the direction of Congress-trump any state

85. Id. at 2 (citing 18 U.S.C. § 922(o), (p) (2000 \& Supp. V 2005)).

86. Id. at 2-3 (citing 18 U.S.C. § 922(g)(1)-(9) (2000)).

87. Id. at 3 (citing 18 U.S.C. § 930 (2000 \& Supp. V 2005); 40 U.S.C. § 5104(e)(1)(A) (Supp. IV 2004); 49 U.S.C. § 46505(b)(1) (2000)).

88. See id. (citing 18 U.S.C. §§ 922(a), (l); 923 (2000 \& Supp. V 2005)).

89. Id. at 3-4 (quoting Brief for the United States in Opposition app. at 1, Emerson v. United States, 536 U.S. 907 (2002) (No. 01-8780)).

90. See id. at 21-25 (arguing that Congress can ban specific types of firearms); id. at 25-26 (arguing that Congress can prohibit certain categories of individuals from possessing firearms); id. at 26-27 (arguing that Congress can regulate commercial transactions involving firearms). Curiously, the U.S. brief did not include a section arguing the constitutionality of category (3) —prohibited locations for carrying firearms. Nonetheless, the Heller majority seemed to endorse that category, as well as expand its application to schools. See Dist. of Columbia v. Heller, 554 U.S. 570, 626 (2008) (" $[\mathrm{N}]$ othing in our opinion should be taken to cast doubt on ... laws forbidding the carrying of firearms in sensitive places such as schools ....”). Notably, the U.S. brief did not mention schools as locations where firearms could validly be prohibited, though this is not surprising given the Supreme Court's invalidation of the Gun Free School Zones Act in United States v. Lopez, 514 U.S. 549 (1995). 
constitutional provisions to the contrary. ${ }^{91}$ Thus, felons prohibited by federal law from possessing firearms can find no comfort in state constitutional provisions, nor can those who might wish to bear arms in locations currently off-limits under federal law, such as airports, schools, courthouses, and perhaps other public buildings. I am not taking issue with any of these restrictions but, rather, simply pointing out that they limit the constitutional choices available to state supreme courts interpreting state constitutional provisions recognizing gun rights.

Thus, in the context of gun rights, the Second Amendment is not the end of the federal story; rather, it is just the beginning. So long as this "right" remains heavily and validly regulated by Congress and the federal government, states will have less power to interpret their state constitutional gun-rights provisions broadly. State supreme courts may interpret their state constitutions to provide greater protections for gun rights, but only if such expanded protections do not conflict with any requirements of federal statutes or regulations. Because of the Supremacy Clause, state constitutions cannot override federal laws restricting the possession, use, and sale of firearms. ${ }^{92}$

Ultimately, the gun-rights situation is another fascinating illustration of dual sovereignty, an interesting and enlightening example of the interaction between federal and state law in the area of personal liberties. The Second Amendment will preclude all governments-federal, state, and local-from banning handgun possession or use in general and from compelling citizens to render ordinary and common weapons such as rifles and shotguns inoperable or ineffective in their own homes. But the Second Amendment right is far from absolute, and indeed the Supreme Court appears to have gone out of its way in Heller to bless the constitutionality of dozens of federal statutes regulating firearm possession, use, and transactions. ${ }^{93}$

Even though the Supreme Court has in a real sense "federalized" the area of gun rights by giving some life and meaning to the Second Amendment, the Court at the same time has made clear that significant federal regulation of gun rights-regulation that is not speculative but already exists in the form of numerous federal statutes-does not violate the Second Amendment. ${ }^{94}$ Because of the Supremacy Clause and existing federal statutory regulation in this area, states are not necessarily

\footnotetext{
91. See U.S. ConST. art. VI, cl. 2.

92. See id.

93. See Heller, 554 U.S. at 626-27.

94. See id.
} 
at liberty to recognize expansive gun rights in their state constitutions. ${ }^{95}$ Or, perhaps more precisely, even if states were to recognize broader individual rights to possess and use firearms, such recognition may be rendered ineffective by the preemptive operation of federal statutory and regulatory law. For example, although states might deem it lawful for citizens to carry weapons in locations such as airports, federal law may preclude giving effect to those state preferences. In such a situation, it is not that the Second Amendment itself limits the states' options. Rather, it is the limited scope of Second Amendment rights combined with preemptive federal legislative and administrative regulation of firearms that precludes giving effect to an expansive recognition of gun rights under state constitutions.

\section{CONCLUSION}

Ultimately, the full scope, nature, and legal bases for an individual's right to keep and bear arms will be determined only after considerable legal "dialogue" that will occur in the federal and state courts, in Congress, in the state legislatures, and in local government bodies. ${ }^{96}$ That is a familiar result under the American system of dual sovereignty, and it is perhaps one of the reasons why we continue to resolve our differences over important topics such as gun rights through public debate, legislative and executive policy initiatives, and litigation in our courts rather than resorting to violence or other unlawful means. An ongoing public dialogue about important issues of individual rights is a necessary result of a system in which both the U.S. Constitution and the

95. The McDonald plurality expressly recognized that incorporation of Second Amendment rights against the states "will to some extent limit the legislative freedom of the States, but this is always true when a Bill of Rights provision is incorporated. Incorporation always restricts experimentation and local variations, but that has not stopped the Court from incorporating virtually every other provision of the Bill of Rights.” McDonald v. City of Chi., 130 S. Ct. 3020, 3050 (2010) (plurality opinion). Unlike with the Second Amendment, there are not dozens of federal statutes directly regulating the individual liberties guaranteed in most Bill of Rights provisions. Thus, the real restriction on the states in the Second Amendment context may not be incorporation of that provision against the states but rather the federal statutory and regulatory scheme that governs firearms and preempts any state constitutional provisions or interpretations that conflict with federal law.

96. In this regard, good lawyers will be those prepared to argue both federal and state constitutional law on behalf of their clients. See Jeffrey S. Sutton, Speech, Why Teach-and Why Study—State Constitutional Law, 34 OKLA. CITY U. L. REV. 165, 178 (2009) ("What is important is that no lawyer worth his or her salt can be a good advocate in today's world without appreciating the possibility - and value - of raising state and federal claims in representing a client.... A lawyer cannot do that today without understanding state constitutional law and appreciating its significance in modern individual-rights disputes.”). 
state constitutions exist to protect the rights of citizens. That the dialogue may at times be wonderfully complex, or perhaps maddeningly so, and that it may last for years, decades, or perhaps never end, are inherent and probably salutary features of the uniquely American system of dual sovereignty. 


\section{APPENDIX}

Table 1: State Constitutional Gun-Rights Provisions

\begin{tabular}{|c|c|c|c|}
\hline State & Constitutional Provision & Citation & Comment \\
\hline Alabama & $\begin{array}{l}\text { "That every citizen has a right } \\
\text { to bear arms in defense of } \\
\text { himself and the state.” }\end{array}$ & $\begin{array}{l}\text { ALA. CONST. } \\
\text { art. I, § } 26 .\end{array}$ & $\begin{array}{l}\text { Self-defense } \\
\text { right explicit }\end{array}$ \\
\hline Alaska & $\begin{array}{l}\text { "A well-regulated militia } \\
\text { being necessary to the security } \\
\text { of a free state, the right of the } \\
\text { people to keep and bear arms } \\
\text { shall not be infringed. The } \\
\text { individual right to keep and } \\
\text { bear arms shall not be denied } \\
\text { or infringed ...." }\end{array}$ & $\begin{array}{l}\text { ALASKA } \\
\text { CONST. art. I, } \\
\S 19 .\end{array}$ & $\begin{array}{l}\text { Second } \\
\text { Amendment } \\
\text { language plus } \\
\text { individual right } \\
\text { explicit }\end{array}$ \\
\hline Arizona & $\begin{array}{l}\text { "The right of the individual } \\
\text { citizen to bear arms in defense } \\
\text { of himself or the state shall } \\
\text { not be impaired, but nothing } \\
\text { in this section shall be } \\
\text { construed as authorizing } \\
\text { individuals or corporations to } \\
\text { organize, maintain, or employ } \\
\text { an armed body of men.” }\end{array}$ & $\begin{array}{l}\text { ARIZ. CONST. } \\
\text { art. II, § } 26 .\end{array}$ & $\begin{array}{l}\text { Self-defense } \\
\text { right explicit }\end{array}$ \\
\hline Arkansas & $\begin{array}{l}\text { "The citizens of this State } \\
\text { shall have the right to keep } \\
\text { and bear arms, for their } \\
\text { common defense." }\end{array}$ & $\begin{array}{l}\text { ARK. CONST. } \\
\text { art. II, § } 5 .\end{array}$ & $\begin{array}{l}\text { "Common } \\
\text { defense" } \\
\text { provision }\end{array}$ \\
\hline California & NO PROVISION & & \\
\hline Colorado & $\begin{array}{l}\text { "The right of no person to } \\
\text { keep and bear arms in defense } \\
\text { of his home, person and } \\
\text { property, or in aid of the civil } \\
\text { power when thereto legally } \\
\text { summoned, shall be called in } \\
\text { question; but nothing herein } \\
\text { contained shall be construed } \\
\text { to justify the practice of } \\
\text { carrying concealed weapons.” }\end{array}$ & $\begin{array}{l}\text { COLO. CONST. } \\
\text { art. II, § } 13 .\end{array}$ & $\begin{array}{l}\text { Self-defense } \\
\text { right explicit }\end{array}$ \\
\hline
\end{tabular}




\begin{tabular}{|c|c|c|c|}
\hline State & Constitutional Provision & Citation & Comment \\
\hline Connecticut & $\begin{array}{l}\text { "Every citizen has a right to } \\
\text { bear arms in defense of } \\
\text { himself and the state." }\end{array}$ & $\begin{array}{l}\text { CONN. CONST. } \\
\text { art. I, § } 15 .\end{array}$ & $\begin{array}{l}\text { Self-defense } \\
\text { right explicit }\end{array}$ \\
\hline Delaware & $\begin{array}{l}\text { "A person has the right to } \\
\text { keep and bear arms for the } \\
\text { defense of self, family, home } \\
\text { and State, and for hunting and } \\
\text { recreational use.” }\end{array}$ & $\begin{array}{l}\text { DEL. CONST. } \\
\text { art. I, § } 20 .\end{array}$ & $\begin{array}{l}\text { Self-defense } \\
\text { right explicit }\end{array}$ \\
\hline Florida & $\begin{array}{l}\text { "The right of the people to } \\
\text { keep and bear arms in defense } \\
\text { of themselves and of the } \\
\text { lawful authority of the state } \\
\text { shall not be infringed, except } \\
\text { that the manner of bearing } \\
\text { arms may be regulated by } \\
\text { law.” }\end{array}$ & $\begin{array}{l}\text { FLA. CONST. } \\
\text { art. I, } \S 8(a) .\end{array}$ & $\begin{array}{l}\text { Self-defense } \\
\text { right explicit }\end{array}$ \\
\hline Georgia & $\begin{array}{l}\text { "The right of the people to } \\
\text { keep and bear arms shall not } \\
\text { be infringed, but the General } \\
\text { Assembly shall have power to } \\
\text { prescribe the manner in which } \\
\text { arms may be borne." }\end{array}$ & $\begin{array}{l}\text { GA. CONST. } \\
\text { art. I, § 1, ๆ } 8 .\end{array}$ & $\begin{array}{l}\text { Recognition of } \\
\text { right without } \\
\text { reference to } \\
\text { militia, common } \\
\text { defense, or self- } \\
\text { defense }\end{array}$ \\
\hline Hawaii & $\begin{array}{l}\text { "A well regulated militia } \\
\text { being necessary to the security } \\
\text { of a free state, the right of the } \\
\text { people to keep and bear arms } \\
\text { shall not be infringed.” }\end{array}$ & $\begin{array}{l}\text { HAW. CONST. } \\
\text { art. I, § } 17 .\end{array}$ & $\begin{array}{l}\text { Second } \\
\text { Amendment } \\
\text { language }\end{array}$ \\
\hline
\end{tabular}




\begin{tabular}{|c|c|c|c|}
\hline State & Constitutional Provision & Citation & Comment \\
\hline Idaho & $\begin{array}{l}\text { "The people have the right to } \\
\text { keep and bear arms, which } \\
\text { right shall not be abridged; } \\
\text { but this provision shall not } \\
\text { prevent the passage of laws to } \\
\text { govern the carrying of } \\
\text { weapons concealed on the } \\
\text { person nor prevent the } \\
\text { passage of legislation } \\
\text { providing minimum } \\
\text { sentences ... nor prevent the } \\
\text { passage of legislation } \\
\text { providing penalties for the } \\
\text { possession of firearms by a } \\
\text { convicted felon ....” }\end{array}$ & $\begin{array}{l}\text { IDAHO CONST. } \\
\text { art. I, § } 11 .\end{array}$ & $\begin{array}{l}\text { Recognition of } \\
\text { right without } \\
\text { reference to } \\
\text { militia, common } \\
\text { defense, or self- } \\
\text { defense }\end{array}$ \\
\hline Illinois & $\begin{array}{l}\text { "Subject only to the police } \\
\text { power, the right of the } \\
\text { individual citizen to keep and } \\
\text { bear arms shall not be } \\
\text { infringed." }\end{array}$ & $\begin{array}{l}\text { ILL. CONST. } \\
\text { art. I, § } 22 .\end{array}$ & $\begin{array}{l}\text { Recognition of } \\
\text { right without } \\
\text { reference to } \\
\text { militia, common } \\
\text { defense, or self- } \\
\text { defense }\end{array}$ \\
\hline Indiana & $\begin{array}{l}\text { "The people shall have a right } \\
\text { to bear arms, for the defense } \\
\text { of themselves and the State.” }\end{array}$ & $\begin{array}{l}\text { IND. CONST. } \\
\text { art. I, § } 32 .\end{array}$ & $\begin{array}{l}\text { Self-defense } \\
\text { right explicit }\end{array}$ \\
\hline Iowa & NO PROVISION & & \\
\hline Kansas & $\begin{array}{l}\text { "A person has the right to } \\
\text { keep and bear arms for the } \\
\text { defense of self, family, home } \\
\text { and state, for lawful hunting } \\
\text { and recreational use, and for } \\
\text { any other lawful } \\
\text { purpose...." }\end{array}$ & $\begin{array}{l}\text { KAN. CONST. } \\
\text { Bill of Rights } \\
\S 4 .\end{array}$ & $\begin{array}{l}\text { Self-defense } \\
\text { right explicit, as } \\
\text { well as other } \\
\text { non-militia uses }\end{array}$ \\
\hline Kentucky & $\begin{array}{l}\text { "All men ... have certain } \\
\text { inherent and inalienable } \\
\text { rights ... [including] ... [t]he } \\
\text { right to bear arms in defense } \\
\text { of themselves and of the State, } \\
\text { subject to the power of the } \\
\text { General Assembly to enact } \\
\text { laws to prevent persons from } \\
\text { carrying concealed weapons." }\end{array}$ & $\begin{array}{l}\text { Ky. CONST. } \\
\text { Bill of Rights } \\
\S 1 .\end{array}$ & $\begin{array}{l}\text { Self-defense } \\
\text { right explicit }\end{array}$ \\
\hline
\end{tabular}




\begin{tabular}{|c|c|c|c|}
\hline State & Constitutional Provision & Citation & Comment \\
\hline Louisiana & $\begin{array}{l}\text { "The right of each citizen to } \\
\text { keep and bear arms shall not } \\
\text { be abridged, but this provision } \\
\text { shall not prevent the passage } \\
\text { of laws to prohibit the } \\
\text { carrying of weapons } \\
\text { concealed on the person." }\end{array}$ & $\begin{array}{l}\text { LA. CONST. } \\
\text { art. I, § } 11 .\end{array}$ & $\begin{array}{l}\text { Recognition of } \\
\text { right without } \\
\text { reference to } \\
\text { militia, common } \\
\text { defense, or self- } \\
\text { defense }\end{array}$ \\
\hline Maine & $\begin{array}{l}\text { "Every citizen has a right to } \\
\text { keep and bear arms and this } \\
\text { right shall never be } \\
\text { questioned." }\end{array}$ & $\begin{array}{l}\text { ME. CONST. } \\
\text { art. I, § } 16 .\end{array}$ & $\begin{array}{l}\text { Recognition of } \\
\text { right without } \\
\text { reference to } \\
\text { militia, common } \\
\text { defense, or self- } \\
\text { defense }\end{array}$ \\
\hline Maryland & NO PROVISION & & \\
\hline Massachusetts & $\begin{array}{l}\text { "The people have a right to } \\
\text { keep and bear arms for the } \\
\text { common defence. And as, in } \\
\text { time of peace, armies are } \\
\text { dangerous to liberty, they } \\
\text { ought not to be maintained } \\
\text { without the consent of the } \\
\text { legislature." }\end{array}$ & $\begin{array}{l}\text { MASS. CONST. } \\
\text { pt. I, } \\
\text { art. XVII. }\end{array}$ & $\begin{array}{l}\text { "Common } \\
\text { defense" } \\
\text { provision }\end{array}$ \\
\hline Michigan & $\begin{array}{l}\text { "Every person has a right to } \\
\text { keep and bear arms for the } \\
\text { defense of himself and the } \\
\text { state." }\end{array}$ & $\begin{array}{l}\text { MICH. CONST. } \\
\text { art. I, § } 6 .\end{array}$ & $\begin{array}{l}\text { Self-defense } \\
\text { right explicit }\end{array}$ \\
\hline Minnesota & NO PROVISION & & \\
\hline Mississippi & $\begin{array}{l}\text { "The right of every citizen to } \\
\text { keep and bear arms in defense } \\
\text { of his home, person, or } \\
\text { property, or in aid of the civil } \\
\text { power when thereto legally } \\
\text { summoned, shall not be called } \\
\text { in question, but the legislature } \\
\text { may regulate or forbid } \\
\text { carrying concealed weapons." }\end{array}$ & $\begin{array}{l}\text { MISS. CONST. } \\
\text { art. III, § } 12 .\end{array}$ & $\begin{array}{l}\text { Self-defense } \\
\text { right explicit }\end{array}$ \\
\hline
\end{tabular}




\begin{tabular}{|c|c|c|c|}
\hline State & Constitutional Provision & Citation & Comment \\
\hline Missouri & $\begin{array}{l}\text { "That the right of every } \\
\text { citizen to keep and bear arms } \\
\text { in defense of his home, person } \\
\text { and property, or when } \\
\text { lawfully summoned in aid of } \\
\text { the civil power, shall not be } \\
\text { questioned; but this shall not } \\
\text { justify the wearing of } \\
\text { concealed weapons." }\end{array}$ & $\begin{array}{l}\text { Mo. Const. } \\
\text { art. I, § } 23 .\end{array}$ & $\begin{array}{l}\text { Self-defense } \\
\text { right explicit }\end{array}$ \\
\hline Montana & $\begin{array}{l}\text { "The right of any person to } \\
\text { keep and bear arms in defense } \\
\text { of his own home, person, and } \\
\text { property, or in aid of the civil } \\
\text { power when thereto legally } \\
\text { summoned, shall not be called } \\
\text { in question, but nothing herein } \\
\text { contained shall be held to } \\
\text { permit the carrying of } \\
\text { concealed weapons." }\end{array}$ & $\begin{array}{l}\text { MONT. } \\
\text { CONST. art. II, } \\
\S 12 .\end{array}$ & $\begin{array}{l}\text { Self-defense } \\
\text { right explicit }\end{array}$ \\
\hline Nebraska & $\begin{array}{l}\text { "All persons . . . have certain } \\
\text { inherent and inalienable } \\
\text { rights; among these ... the } \\
\text { right to keep and bear arms } \\
\text { for security or defense of self, } \\
\text { family, home, and others, and } \\
\text { for lawful common defense, } \\
\text { hunting, recreational use, and } \\
\text { all other lawful purposes, and } \\
\text { such rights shall not be denied } \\
\text { or infringed by the state ...." }\end{array}$ & $\begin{array}{l}\text { NEB. CONST. } \\
\text { art. I, § } 1 .\end{array}$ & $\begin{array}{l}\text { Self-defense } \\
\text { right explicit, as } \\
\text { well as other } \\
\text { non-militia uses }\end{array}$ \\
\hline Nevada & $\begin{array}{l}\text { "Every citizen has the right to } \\
\text { keep and bear arms for } \\
\text { security and defense, for } \\
\text { lawful hunting and } \\
\text { recreational use and for other } \\
\text { lawful purposes.” }\end{array}$ & $\begin{array}{l}\text { NEV. CONST. } \\
\text { art. I, § 11(1). }\end{array}$ & $\begin{array}{l}\text { Self-defense } \\
\text { right explicit, as } \\
\text { well as other } \\
\text { non-militia uses }\end{array}$ \\
\hline $\begin{array}{c}\text { New } \\
\text { Hampshire }\end{array}$ & $\begin{array}{l}\text { "All persons have the right to } \\
\text { keep and bear arms in defense } \\
\text { of themselves, their families, } \\
\text { their property and the state." }\end{array}$ & $\begin{array}{l}\text { N.H. CONST. } \\
\text { pt. I, art. 2-a. }\end{array}$ & $\begin{array}{l}\text { Self-defense } \\
\text { right explicit }\end{array}$ \\
\hline New Jersey & NO PROVISION & & \\
\hline
\end{tabular}




\begin{tabular}{|c|c|c|c|}
\hline State & Constitutional Provision & Citation & Comment \\
\hline New Mexico & $\begin{array}{l}\text { "No law shall abridge the } \\
\text { right of the citizen to keep and } \\
\text { bear arms for security and } \\
\text { defense, for lawful hunting } \\
\text { and recreational use and for } \\
\text { other lawful purposes, but } \\
\text { nothing herein shall be held to } \\
\text { permit the carrying of } \\
\text { concealed weapons." }\end{array}$ & $\begin{array}{l}\text { N.M. CONST. } \\
\text { art. II, § } 6 .\end{array}$ & $\begin{array}{l}\text { Self-defense } \\
\text { right explicit, as } \\
\text { well as other } \\
\text { non-militia uses }\end{array}$ \\
\hline New York & NO PROVISION & & \\
\hline $\begin{array}{c}\text { North } \\
\text { Carolina }\end{array}$ & $\begin{array}{l}\text { "A well regulated militia } \\
\text { being necessary to the security } \\
\text { of a free State, the right of the } \\
\text { people to keep and bear arms } \\
\text { shall not be infringed . ..." }\end{array}$ & $\begin{array}{l}\text { N.C. Const. } \\
\text { art. I, § } 30 .\end{array}$ & $\begin{array}{l}\text { Second } \\
\text { Amendment } \\
\text { language }\end{array}$ \\
\hline North Dakota & $\begin{array}{l}\text { “All individuals . . . have } \\
\text { certain inalienable rights, } \\
\text { among which are . . . to keep } \\
\text { and bear arms for the defense } \\
\text { of their person, family, } \\
\text { property, and the state, and for } \\
\text { lawful hunting, recreational, } \\
\text { and other lawful purposes, } \\
\text { which shall not be infringed.” }\end{array}$ & $\begin{array}{l}\text { N.D. CONST. } \\
\text { art. I, § } 1 .\end{array}$ & $\begin{array}{l}\text { Self-defense } \\
\text { right explicit, as } \\
\text { well as other } \\
\text { non-militia uses }\end{array}$ \\
\hline Ohio & $\begin{array}{l}\text { "The people have the right to } \\
\text { bear arms for their defense } \\
\text { and security; but standing } \\
\text { armies, in time of peace, are } \\
\text { dangerous to liberty, and shall } \\
\text { not be kept up; and the } \\
\text { military shall be in strict } \\
\text { subordination to the civil } \\
\text { power." }\end{array}$ & $\begin{array}{l}\text { OHIO CONST. } \\
\text { art. I, § } 4 .\end{array}$ & $\begin{array}{l}\text { Self-defense } \\
\text { right explicit }\end{array}$ \\
\hline
\end{tabular}




\begin{tabular}{|c|c|c|c|}
\hline State & Constitutional Provision & Citation & Comment \\
\hline Oklahoma & $\begin{array}{l}\text { "The right of a citizen to keep } \\
\text { and bear arms in defense of } \\
\text { his home, person, or property, } \\
\text { or in aid of the civil power, } \\
\text { when thereunto legally } \\
\text { summoned, shall never be } \\
\text { prohibited; but nothing herein } \\
\text { contained shall prevent the } \\
\text { Legislature from regulating } \\
\text { the carrying of weapons.” }\end{array}$ & $\begin{array}{l}\text { OKLA. CONST. } \\
\text { art. II, § } 26 .\end{array}$ & $\begin{array}{l}\text { Self-defense } \\
\text { right explicit }\end{array}$ \\
\hline Oregon & $\begin{array}{l}\text { "The people shall have the } \\
\text { right to bear arms for the } \\
\text { defence (sic) of themselves, } \\
\text { and the State, but the Military } \\
\text { shall be kept in strict } \\
\text { subordination to the civil } \\
\text { power[.]" }\end{array}$ & $\begin{array}{l}\text { OR. CONST. } \\
\text { art. I, § } 27 .\end{array}$ & $\begin{array}{l}\text { Self-defense } \\
\text { right explicit }\end{array}$ \\
\hline Pennsylvania & $\begin{array}{l}\text { "The right of the citizens to } \\
\text { bear arms in defence of } \\
\text { themselves and the State shall } \\
\text { not be questioned." }\end{array}$ & $\begin{array}{l}\text { PA. CONST. } \\
\text { art. I, § } 21 .\end{array}$ & $\begin{array}{l}\text { Self-defense } \\
\text { right explicit }\end{array}$ \\
\hline Rhode Island & $\begin{array}{l}\text { "The right of the people to } \\
\text { keep and bear arms shall not } \\
\text { be infringed." }\end{array}$ & $\begin{array}{l}\text { R.I. CONST. } \\
\text { art. I, § } 22 .\end{array}$ & $\begin{array}{l}\text { Recognition of } \\
\text { right without } \\
\text { reference to } \\
\text { militia, common } \\
\text { defense, or self- } \\
\text { defense }\end{array}$ \\
\hline $\begin{array}{c}\text { South } \\
\text { Carolina }\end{array}$ & $\begin{array}{l}\text { "A well regulated militia } \\
\text { being necessary to the security } \\
\text { of a free State, the right of the } \\
\text { people to keep and bear arms } \\
\text { shall not be infringed. As, in } \\
\text { times of peace, armies are } \\
\text { dangerous to liberty, they } \\
\text { shall not be maintained } \\
\text { without the consent of the } \\
\text { General Assembly.” }\end{array}$ & $\begin{array}{l}\text { S.C. CONST. } \\
\text { art. I, § } 20 .\end{array}$ & $\begin{array}{l}\text { Second } \\
\text { Amendment } \\
\text { language }\end{array}$ \\
\hline South Dakota & $\begin{array}{l}\text { "The right of the citizens to } \\
\text { bear arms of defense of } \\
\text { themselves and the state shall } \\
\text { not be denied." }\end{array}$ & $\begin{array}{l}\text { S.D. CONST. } \\
\text { art. VI, § } 24 .\end{array}$ & $\begin{array}{l}\text { Self-defense } \\
\text { right explicit }\end{array}$ \\
\hline
\end{tabular}




\begin{tabular}{|c|c|c|c|}
\hline State & Constitutional Provision & Citation & Comment \\
\hline Tennessee & $\begin{array}{l}\text { "That the citizens of this State } \\
\text { have a right to keep and to } \\
\text { bear arms for their common } \\
\text { defense; but the Legislature } \\
\text { shall have power, by law, to } \\
\text { regulate the wearing of arms } \\
\text { with a view to prevent crime." }\end{array}$ & $\begin{array}{l}\text { TENN. CONST. } \\
\text { art. I, § } 26 .\end{array}$ & $\begin{array}{l}\text { “Common } \\
\text { defense” } \\
\text { provision }\end{array}$ \\
\hline Texas & $\begin{array}{l}\text { "Every citizen shall have the } \\
\text { right to keep and bear arms in } \\
\text { the lawful defense of himself } \\
\text { or the State; but the } \\
\text { Legislature shall have power, } \\
\text { by law, to regulate the } \\
\text { wearing of arms, with the } \\
\text { view to prevent crime.” }\end{array}$ & $\begin{array}{l}\text { TEX. CONST. } \\
\text { art. I, § } 23 .\end{array}$ & $\begin{array}{l}\text { Self-defense } \\
\text { right explicit }\end{array}$ \\
\hline Utah & $\begin{array}{l}\text { "The individual right of the } \\
\text { people to keep and bear arms } \\
\text { for security and defense of } \\
\text { self, family, others, property, } \\
\text { or the state, as well as for } \\
\text { other lawful purposes shall } \\
\text { not be infringed; but nothing } \\
\text { herein shall prevent the } \\
\text { Legislature from defining the } \\
\text { lawful use of arms.” }\end{array}$ & $\begin{array}{l}\text { UTAH CONST. } \\
\text { art. I, § } 6 .\end{array}$ & $\begin{array}{l}\text { Self-defense } \\
\text { right explicit }\end{array}$ \\
\hline Vermont & $\begin{array}{l}\text { "That the people have a right } \\
\text { to bear arms for the defence of } \\
\text { themselves and the State-- } \\
\text { and as standing armies in the } \\
\text { time of peace are dangerous to } \\
\text { liberty, they ought not to be } \\
\text { kept up; and that the military } \\
\text { should be kept under strict } \\
\text { subordination to and governed } \\
\text { by the civil power." }\end{array}$ & $\begin{array}{l}\text { VT. CONST. } \\
\text { ch. } 1 \text {, } \\
\text { art. XVI. }\end{array}$ & $\begin{array}{l}\text { Self-defense } \\
\text { right explicit }\end{array}$ \\
\hline
\end{tabular}




\begin{tabular}{|c|c|c|c|}
\hline State & Constitutional Provision & Citation & Comment \\
\hline Virginia & $\begin{array}{l}\text { "That a well regulated militia, } \\
\text { composed of the body of the } \\
\text { people, trained to arms, is the } \\
\text { proper, natural, and safe } \\
\text { defense of a free state, } \\
\text { therefore, the right of the } \\
\text { people to keep and bear arms } \\
\text { shall not be infringed ...." }\end{array}$ & $\begin{array}{l}\text { VA. CONST. } \\
\text { art. I, § } 13 .\end{array}$ & $\begin{array}{l}\text { "Militia” } \\
\text { purpose, but } \\
\text { variation from } \\
\text { the Second } \\
\text { Amendment } \\
\text { language }\end{array}$ \\
\hline Washington & $\begin{array}{l}\text { "The right of the individual } \\
\text { citizen to bear arms in defense } \\
\text { of himself, or the state, shall } \\
\text { not be impaired, but nothing } \\
\text { in this section shall be } \\
\text { construed as authorizing } \\
\text { individuals or corporations to } \\
\text { organize, maintain or employ } \\
\text { an armed body of men.” }\end{array}$ & $\begin{array}{l}\text { WASH. } \\
\text { CONST. art. I, } \\
\S 24 .\end{array}$ & $\begin{array}{l}\text { Self-defense } \\
\text { right explicit }\end{array}$ \\
\hline West Virginia & $\begin{array}{l}\text { "A person has the right to } \\
\text { keep and bear arms for the } \\
\text { defense of self, family, home } \\
\text { and state, and for lawful } \\
\text { hunting and recreational use." }\end{array}$ & $\begin{array}{l}\text { W. VA. } \\
\text { CONST. art. } \\
\text { III, § } 22 .\end{array}$ & $\begin{array}{l}\text { Self-defense } \\
\text { right explicit, as } \\
\text { well as other } \\
\text { non-militia uses }\end{array}$ \\
\hline Wisconsin & $\begin{array}{l}\text { "The people have the right to } \\
\text { keep and bear arms for } \\
\text { security, defense, hunting, } \\
\text { recreation or any other lawful } \\
\text { purpose." }\end{array}$ & $\begin{array}{l}\text { WIS. CONST. } \\
\text { art. I, § } 25 .\end{array}$ & $\begin{array}{l}\text { Self-defense } \\
\text { right explicit, as } \\
\text { well as other } \\
\text { non-militia uses }\end{array}$ \\
\hline Wyoming & $\begin{array}{l}\text { "The right of the citizens to } \\
\text { bear arms in defense of } \\
\text { themselves and of the state } \\
\text { shall not be denied." }\end{array}$ & $\begin{array}{l}\text { WYO. CONST. } \\
\text { art. I, § } 24 .\end{array}$ & $\begin{array}{l}\text { Self-defense } \\
\text { right explicit }\end{array}$ \\
\hline
\end{tabular}

